\title{
Death and the Control of Life in an Indonesian City
}

\author{
Robbie Peters \\ Anthropology department, The University of Sydney \\ Robbie.peters@sydney.edu.au
}

\begin{abstract}
Death represents sovereignty and through it people negotiate their existence, concludes Claudio Lomnitz (2008:496) in his history of Mexican death. This conclusion holds true for the politics of death in the city of Surabaya, Indonesia, but only if death is understood in topographic and genealogical terms; or, in other words, in terms of land and one's ancestral/genealogical connection to it. Through a discussion of the politics of land occupation and of the production, commemoration, and denial of death in post-colonial Surabaya, I present a 'topogenic' history of death as an instructive way of understanding state-society relations in that city. Throughout the article, I ground that history in the kampong's social institutions of the communal meal and prayer (slametan) and the guard (gardu) as vehicles for the expression of an inviolable topogenic sovereignty.
\end{abstract}

\section{Keywords}

death - violence - communist - Surabaya - slametan - land

Based on fieldwork in the mid 1950s near the East Javanese town of Pare, Robert Jay (1969:111) referred to the 'posthumous bond' between living and dead residents as 'strong and real', and as the basis of a village community that is most realized during the communal meal, or slametan. Clifford Geertz (1960:11), Jay's contemporary in Pare, studied the slametan in more detail and termed it a furtive little ritual at the centre of the Javanese religious system and village society, yet somehow peripheral to the nascent Indonesian state. Geertz (1963:147) held that 'Indonesia as a nation is not the village or the small town writ-large. It is an autonomous social system.' Through a focus on the kampung (low-income urban neighbourhood; hereafter kampong) in Surabaya

(C) ROBBIE PETERS, 2016 DOI: 10.1163/22134379-17202004 
since the 1950s, this paper turns that notion on its head by showing that the larger social system of the nation-state has been in ongoing struggle with the village as a sovereign territorial unit. I show how kampong residents have enacted that sovereignty through the inclusive communal meal (slametan) and the defensive neighbourhood guard (gardu), and how the state has intervened to contain it. Drawing on archival and oral sources and a total of almost two years of fieldwork in the kampong of Dinoyo since January 1998, and using the kampong as the contextual lens, I show how institutions like the slametan and the gardu are not benign cultural forms, but potent political expressions of local territorial sovereignty. In so doing, I extend upon a well-established literature on death and its commemoration as expressions of community in Java.

A simple grave typically marks the resting place of the founding father (sesepuh) of the village in Java. In the graveyard of the inner-city kampong of Dinoyo in Surabaya sits one such grave; it holds the remains of Dinoyo's founding father, Cakacoyo, and is sheltered by a frangipani tree that was planted upon his death. Using the common Javanese botanic metaphor of seeding and sprouting, the graveyard's caretaker (juru kunci) described the tree as representing the growth of the kampong, stating: '[T]he seed and the roots that sprout from it [...] represent the tree's foundation, the founding father; while the stem, branches, leaves and flowers represent the kampong community, growing and renewing from that foundation.' ${ }^{1}$ Like the many other founding fathers buried in Surabaya, however, Cakacoyo's spiritual potency does not extend beyond the kampong in which he rests.

Cakacoyo's grave is the lesser of two other spiritually significant graves located nearby, but outside the kampong. The most well known is the Makam Bungkul, which sits a kilometre away in a mausoleum on the edge of Surabaya's busiest park. Reportedly one of the oldest of the thousands of such graves in Java, and older than those of the nine apostles of Javanese Islam, it holds the remains of Sunan Bungkul (1400 CE), an early Javanese Muslim and crafter of daggers (keris) for the Majapahit kingdom (Akhudiat 2008:88). Nearby, behind a colonial mansion from the 1920s, sits the grave of Bungkul's chariot driver, Pak Usir, who Dinoyo residents claim was Cakacoyo's ancestor. The first grave, located in a public mausoleum, the second, along a street, and the third, in a kampong establish a 'hierarchy of location' that places the kampong grave at the bottom and the public mausoleum at the top (Harding 1992:131). This locational hierarchy accords to a Javanese idea of power that Soemarsiad Moertono

1 Graveyard caretaker, personal communication, 12-3-2008. 
(2009 [1968]:124) best defined using the metaphor of a ray of light that spans out from its centre and weakens at its periphery, where another centre, drawing legitimacy from the original, begins. These graves project such power by constituting what James Fox (1997:13) terms 'topogenies', which tie a genealogy to a topographic location. In the inclusive Javanese kinship system, many who live in a particular village share their ancestry with its founding father, making him their most important saint. Thus, while Cakacoyo is the lesser of the three saints buried in the area, he was the one who offered Dinoyo residents the most 'power and protection', demonstrating that spiritual potency is both concentrated and dispersed among multiple centres (Keeler 1987:85; Fox 1997:12).

\section{'Being Part of One Body': The Slametan}

Fox (2002:172) holds that such graves serve as 'broadcast centres' via the gatekeeper into the traditions of the ancestor who rests there. However, for a figure like Cakacoyo, who is visited only by Dinoyo residents, this broadcast function shifts to the welcome speech (ujub) given to guests at a slametan. A common ritual in Surabaya's kampongs, the slametan brings together new and old residents to commemorate a major event in the life cycle of a neighbour or an event in local history. The welcome speech welcomes the guests, explains the purpose of the slametan, and identifies the local spirits to whom the meal is dedicated and the local community to whom it is presented (Geertz 1960:123; Keeler 1987:157; Woodward 1988:74; Beatty 1999:37). In Dinoyo, the speaker speaks on behalf of the host as his wakil (representative) and relies on references to a symbolic dish called ketan intip: a pudding-like combination of sticky rice, boiled egg, grated coconut, palm-sugar and shredded bandeng fish. Served at midnight before a neighbour's wedding day or a significant day on the national, Islamic, or Javanese calendars, ketan intip provides the speaker with symbolic reference points that help him explain to participants the idea of rukun, or communal harmony. Agus, a 72-year-old man who gave welcome speeches and who watched his father do the same in the 1950s, suggests that the speeches teach new residents about Dinoyo's inclusive traditions: a pedagogical function he believes was most useful after Independence, when thousands of newcomers moved into the kampong from the depressed countryside. Agus explains how his father would address the audience during a typical welcome speech in the 1950s:

Sitting cross-legged with neighbours around a dish of ketan intip, my father would begin by briefly explaining that the dish was a favourite of 
Cakacoyo [the founding father/sesupuh of Dinoyo] and is prepared for special occasions like this so as to remember him and the traditions he practised and passed down. My father would then interpret the meaning of each ingredient in ketan intip. Beginning with the egg, he would present a symbol of revelation through sacrifice in the form of the hen, which must sit on the egg for three days without eating to make it hatchmuch like man, who must fast and persist if he wants to reach a higher awareness that reveals anything of worth. My father would then present the bandeng fish as a symbol of group sacrifice in the manner of a fish in a pond that cannot reproduce and proliferate as it could in a stream and soon learns that it must surrender its freedoms to live among others. Finally, he would present the pounded sticky-rice as a symbol of cohesion, or coagulation into an inseparable mass, which he says man must be like if he is to be at one with his fellows.

My father, like anyone else who did the introduction, spoke to neighbours in a humble way that showed he knew as much about it as many of them did and that he may have missed some points about it. Usually at the beginning or end of the speech he would apologize for his ignorance of the [local] tradition or for not having got it completely right. ${ }^{2}$

The speaker's main task was to establish the humility of himself and the host by speaking on the host's behalf in humble tones that decentred power from them to the audience (Keeler 1987:164; Woodward 1988: 75). In Dinoyo, a further decentring was achieved through the Low-Javanese dialect (ngoko) of its residents. An egalitarian language, ngoko was the only Javanese language they shared, with few capable of the higher forms of madya or kromo spoken in Central Java.

\section{New and Old Residents}

Agus attests that the only status difference among guests at a slametan was between original inhabitants (warga kampung) and newcomers (pendatang). Original inhabitants traced their ancestry to the area's first settlers, who were later given usufruct right to the land by its purchasing landlord (typically a person of Chinese, Arab, or European descent) in exchange for their labour on his cash crop, or their payment to him of a land rent (Heemstra 1940).

2 Agus, personal communication, 23-12-2011. 
After Surabaya became a self-governing and autonomous municipality in 1906, private landlords and the municipal government purchased most of the land in the southern half of the city, greatly expanding the number of kampong dwellers under their de facto authority (Basundoro 2013:58, 2012:14). By 1916, they had alienated 1,445 hectares, displacing over 16,0oo people into the few remaining kampongs, where garden plots and sawah gave way to makeshift shacks to house the displaced (Basundoro 2013:79-86; Dick 2003:345-57, Frederick 1978:41, 61). Original inhabitants incorporated the displaced into the obligations of kampong membership, such as attendance at slametan, neighbourhood working-bees, and guard post duties. An important obligation was the rejection of landlord authority, which in 1916 formed a popular, citywide movement supported by nascent nationalist organizations and, on occasion, the municipal court (Kartodirdjo 1973:37; Basundoro 2009:79-84; Dick 2003:355). Despite its broad support, the assertion of occupant rights did not stop the punitive authority of the landlords. By 1931, landlords had alienated 10,500 square metres of land for development in an area stretching south from the old central business district at Jembatan Merah to the city's southern border at Wonokromo, embittering kampong dwellers, who were either displaced or hemmed in by the modern European buildings and factories constructed along the ever-decreasing perimeter of their kampongs (Von Faber 1934:176; Dick 2003:358). By the closing years of colonial rule, mass evictions at the kampongs Kedongdoro and Kalibutuh by their respective landlords and the requirement that residents of private estates must gain landlord permission for building works they undertook, served as a bitter reminder of the weakness of the kampong dweller's claim to land in the city. ${ }^{3}$

In the newly independent Surabaya of the early 1950s, the municipal government instructed the 35 remaining landlords of private estates in Surabaya to pay eviction costs, fence the land, and pay the next few years of rent for those they displaced — demands the landlords could not afford, forcing them to abandon the land to its occupiers (Colombijn 2010:212; Dick 2003:369). In the first few years after Independence, with Surabaya's European population half of what it was before the Second World War and its Indonesian population double what it was, the city became 'Indonesianized' and its kampongs flooded with newcomers who lacked formal work or residency status. To tackle the problem, the mayor resorted to asking his counterparts in East Java's towns to take the impossible step of trying to stop outmigration to Surabaya and of taking back the many poor newcomers entering the city

3 Pembela Rakjat, 24-3-1940, 27-3-1940, 10-4-1940. 
(Basundoro 2013:271, 245). Kampong dwellers were left to bear the brunt of the demographic crisis, which took the form of ragged strangers sleeping outside one's house, cooking in one's hearth, and washing by one's well. Yet, the small clustering of neighbours that formed tight-knit units of cooperation in the kampongs were often incapable, even with police help, of keeping out the more numerous newcomers. ${ }^{4}$ Aside from making them pay rent for the space they occupied, neighbours dealt with newcomers through the conventional Javanese strategy of incorporating them into the community by merging what Maurice Block (1971:10o) termed 'practical cooperation and kinship relations'.

\section{Converting Them into Us}

In the Javanese model of centrifugal kinship, one marries an outsider to incorporate them into the obligations of family and neighbourhood. As Shelly Errington (1987:420-1) put it: 'They are converted into Us by the next generational layer', giving the children a blood link to the original inhabitant, from whom one's autochthonous claim to the kampong stems. Based on his research in the hinterland town of Pare in the mid 1950s, Robert Jay (1969:67) put it less abstractly, stating: 'Children tie together their parents' separate property rights and certain of their social and ritual ties to each other's kinsmen.' Reaching into the past and the present, those ties were sanctified in a slametan through the 'Us' it presents in the death it commemorates. Death, notes Errington (1987:438), 'is an ideal state, the state of the Ancestor, the state that eradicates difference.' In a slametan, this state took the sensory form of what an informant described to anthropologist James Peacock (1968:94) in Surabaya in the early 1960 s as the feeling of being 'part of one body': a feeling that relied on a bond with the dead, not just the living. Similarly, Jay (1969:111) held that 'the posthumous bond is strong and real', and was most noticeable in 'the gift of food' given to the deceased in exchange for their forgiveness and protection of the living. As an informant told Jay (1969:112), '[a]ll real Javanese recognise the existence of the afterlife and of the souls of the dead as still having the quality of the living. Any normal person just naturally feels this way.' Making a similar point, an informant speaking to Peacock (1968:98) connected the posthumous bond to the slametan welcome speech, asserting that the speech must 'honour the ancestors'; if not, it fails to achieve slamet (peace).

4 Basundoro 2013:188-9; Pewarta Surabaja, 15-5-1952. 
Communication between the living and the dead was sensory, flowing through such things as offerings of food to honour the dead in exchange for their protection of the living. Whether through the aroma of the slametan food that Geertz (1960:15) was told the dead could smell, or the humble tones of the speaker at a welcome speech, the senses were potent mediums of communication that united the living and the dead. The basic sensory expression of this unity was the experience of collective inner peace, or 'homeostasis', in which one's mind and body shared with those of its neighbours a state of emotionless serenity (ikhlas): a state that found its ideal reflection in the tensionless face of the corpse at a neighbourhood funeral as a model of appropriate expression for the living. The ideal Central Javanese person is like a dead person, noted James Siegel (1986:270), who wrote: 'The self that goes out of existence when one dies is the speaker of Low Javanese. The speaker of High Javanese is, ideally, equated with the "dead" even before his biological death.'

What, then, of the East Javanese kampong dwellers, many of whom are incapable of High Javanese and can only speak Low Javanese? For them, unity is not achieved by detaching oneself from life, but by engaging with it: a concept they term nerimo, or accepting the world around them. When considering the slametan of East Java, Siegel (2000:193, 197) later acknowledged that what mattered most among its participants was their 'tolerance' of one another's differences. Based on his research in East Java in the late 1970s, Robert Heffner (1985:154-5) argued that nerimo best captured the East Javanese attitude to the posthumous bond, but did so through sensory attitudes that were 'linked to activities in this world'. He held that nerimo found practical expression in the inviting of neighbours to a slametan and the involving of them in the preparation of the food and the hosting of guests, and found its ultimate expression in the unpleasing task of washing a deceased relative for burial.

James Peacock (1967:345, 351-4, 1968:172) noted in the early 196os that Surabaya's kampong residents considered nerimo a most powerful compulsion that forced them to invite into their lives the often unpleasing world beyond, and found expression in the seductive clown dance, the ngremo, in which the dancer entices the spectators to participate. However, Peacock (1967) showed that there is more to nerimo than an all-inclusive ethic of invitation and participation. At the heart of nerimo was a tension between the acceptance of people into one's life and the fear of being troubled by them. This was a powerful theme in the 1950s and 196os, when kampong residents had to learn to live with the poor newcomers who were flooding into the city in unprecedented numbers. It was a theme played out in ludruk, an East Javanese comedic drama, through its wandering clown figure who typically enters a kampong 
home and, taking advantage of the host's obligatory hospitality, swindles him of his cash, elopes with his daughter, or lodges in his home and usurps him of it (Peacock 1967:352-3, 1968:136-8). Ludruk emphasized this fear of encroachment within nerimo and its implicit sense of a boundary between insider and outsider, which was portrayed through the breaching of this boundary by a culturally ignorant clown who enters a home without declaring his presence or requesting permission to enter (Peacock 1967:353, 1968:134). In ludruk, the conservative host was always the loser, never able to maintain the integrity of this boundary and forced to come to terms with the world outside the kampong (Peacock 1968:119). As Peacock noticed (1967:355-6), 'whereas the slametan imbeds kampung dwellers in localised kampung groups, ludruk pulls them in the opposite direction-out of the kampung [...] [with] songs and melodramas [that] directly seduce kampung dwellers into the system'. In so doing, ludruk achieved what the slametan did not: a blurring of the boundary between neighbourhood and city. The slametan maintained this boundary by presenting a distinct, local community in the form of those who participate-typically neighbours and those known to them. Those not known must detour around the event, which occupies all or part of a kampong alleyway, preventing people from walking through. Those who do walk through risk being reprimanded, interrogated, or beaten by the participants.

In response to Andrew Beatty's (1999:48-9) finding that the slametan defines no distinct community because the 'multivocality' of the symbols in the rite enable all people to participate in it and find meaning, Siegel (2000:196) made the important point that despite this, and despite occurring throughout Java, slametan are local in the first place because the sprits referred to in the rite are local'. As Siegel (2000:196) contends, 'there is a local community and the slametan is its ritual expression'. As the nerimo emotion shows, however, fear and guardedness underline this seemingly inclusive notion of local community.

What, then, of the spiritual or emotional content of the local community formed by the official administrative unit of neighbourhood and its functionary, the neighbourhood head? Peacock (1968:93) described the duties of the neighbourhood head as procedural and bureaucratic: 'He registers births, marriages, deaths and guests of homes within his jurisdiction. He assesses his households to finance collective projects. He organises a night watch against thieves.' The community formed by these actions did not cohere with the one that ate, smelled, heard, and witnessed together during a slametan. As Geertz (1960:12) noted, community was based on a vaguely defined territory that materialized — during a death slametan for example — when a boy from the deceased's family walked the alleyways to notify neighbours of the death by 
beating the warning gong. This vague territory stretched only as far as the boy's voice or gong beat could carry: a sensory territory formed by sounds that made no discriminations other than the ability to hear, and bore no resemblance to the administratively defined unit of 'neighbourhood'.

\section{The Receptive and Defensive Body: Melekan}

The sensory unity of the posthumous bond was also achieved by staying up throughout the night to bring oneself in touch with the ancestors. Peacock (1968:23) noted that ' $[\mathrm{k}]$ ampung dwellers [...] are up at daybreak and stay up until midnight on weeknights or all night at weekend celebrations'. Without knowing it, Peacock was pointing to a seemingly uncomplicated rite called melekan, which involved kampong men gathering in the alleyway throughout the night on weekends or after a slametan to talk, smoke, and contemplate. Pointing to a seeming contradiction between the passive body of these actions and the alert body implied by the root word melek (lit. eyes open), a group of old men from Dinoyo explained that the term assumed awareness rather than alertness. Referring to a key moment in the life of the Prophet Muhammad that is expressed in the Quran and the Hadith and well known to all Muslims, these men explained that the first revelation that Muhammad received was that he must 'read', which they interpreted as meaning that he must 'open his eyes, his mind, and his heart to the world'. Melekan put this principle of openness and receptivity into a ritualized form that helped men achieve an awareness of God, of the ancestors, and of their traditions. According to kampong men and their Sufi beliefs, one is closest to such awareness at midnight, when prayer is most spiritually enriching: a tenet that appears in many Hadith through eyewitness accounts of the Prophet Muhammad saying such things as 'they slept but little at night'; 'in the later part of the night there is the presence of angels and Prayer at that time is best'; 'feed people, strengthen the ties of kinship and be in Prayer when others are asleep' (Khan 1975:204-5, 165). Kampong men often referred to these tenets to give meaning to melekan as a rite that occurred at midnight so as to bring participants into closer awareness of the founding father, who they say is an example of exemplary spiritual practice through his habit of staying up at night to guard, pray, and share simple food with neighbours.

While melek demanded a passive and receptive body of open mind and open heart, it also demanded a vigilant and defensive one that enforced subservience in those who were not aware: those whose eyes were not open. This vigilant aspect of melekan involved exercising the martial justice necessary to guard 
kampong boundaries and the traditions that lay within. A young man explained to Peacock (1968:96) how this martial justice worked, stating:

A group of boys are sitting around the entrance to our kampong. Some fellow wants to ride a bicycle hard through the entrance. He doesn't want to ask permission in an alus way to enter with his bicycle. We beat him up, then tell him, 'You are Javanese but have not yet learned to understand Javanese manners!'

Normally, a person entering the kampong must respect the neighbours by conveying an air of humility. If not conveyed, humility had to be enforced to make the person see where they had gone wrong, to teach them a lesson (kapok). This enforced seeing helped the wrongdoer see the spiritual sanctity of the kampong that its men saw during melekan. By making one see and surrender to this sanctity of territory, guarding achieved what the ketan intip rite achieved: a unification of the living through their remembrance of the dead. In both cases, these rituals had the pedagogical function of reminding residents and teaching newcomers.

\section{Wild Ground}

Katherine Verdery (1999:40) suggests that when sovereignty is based on territory consecrated by the grave of a common ancestor, it 'challenges the entire national genealogy', which she calls 'a kind of ancestor worship, a system of patrilineal kinship, in which national heroes occupy the place of clan elders'. This genealogical challenge is actualized through violence. However, only the nation-state has the right to define boundaries and citizens through violence, making guard-post violence an illegitimate appropriation of that right.

In the early 1950s, the army and municipality issued regular public instructions declaring their suzerainty of all land in the city and their right to protect it with violence. They deemed as 'wild ground' any land that had been abandoned, taken over by squatters, or that lay in abeyance due to its disputed ownership. Such land included graveyards, riverbanks, untended fields, unoccupied buildings, vacant plots, rail sidings, rubbish dumps, and even kampongs on private land. Considering it a breeding ground for disease, the municipality declared in January 1953 that it would eliminate wild ground. ${ }^{5}$ By Decem-

5 Jawa Pos, 16-1-1953, 6-2-1953. 
ber, the police and army had demolished over half of the 5,00o or so squatter shacks that stood on wild ground, filled in many of the 'wild latrines' that had been dug there, killed many of the rabies-infected dogs that roamed there, and conducted daily round-ups of the homeless who lived there and of the syphilisinfected prostitutes who plied their trade there. ${ }^{6}$ To tackle those who claimed wild ground, the municipality instructed in January $195^{2}$ that those unable to prove that they bought their land must surrender it to the state, and those who could prove they bought it must sell it to the state. ${ }^{7}$ Yet, both confiscation and purchase were difficult because occupiers either challenged the municipality over its vague definition of rightful ownership or asserted their right to demand a specified value for their land. ${ }^{8}$

The municipality also lacked the administrative capacity to mediate all the land claims and disputes and issue land use permits, resulting each year in hundreds of unresolved claims from the previous year piling up on civil servants' desks and hundreds of plots and buildings around the city existing in a state of abeyance. ${ }^{9}$ After the nationalization of foreign enterprises in 1957, the municipality more frequently declared its right to untitled land by fining those who refused to move from it or who tried to sell it. ${ }^{10}$ Yet, despite this more steadfast approach, municipal suzerainty of wild ground was more rhetorical than real, with squatters openly contesting the public instructions and legal injunctions against occupation. In real terms, municipal control of wild ground had translated since Independence to the municipality repurchasing a little over 1,00o hectares. ${ }^{11}$

By the early 1950s, about seven hundred hectares of land deemed wild ground belonged to absentee landlords, who lacked the money and political support to evict their squatters, while the municipality lacked the money to purchase the land, leaving much of it to those who occupied the kampongs that now stretched across it. ${ }^{12}$ By January 1958, a municipal decree requiring all foreign private-estate owners of land greater than 10 hectares to bequeath it to its occupiers or surrender it to the municipality had resulted in more land falling under the tacit control of kampong dwellers..$^{13}$ By September, the

\footnotetext{
6 Surabaya Pos, 21-12-1953; Pewarta Surabaya, 4-2-1952, 6-2-1952; Jawa Pos, 6-1-1953.

7 Perdamaian, 14-1-1952, 22-1-1952.

8 Jawa Pos, 29-1-1952, 11-2-1952; Pewarta Surabaya, 27-4-1953.

9 Perdamaian, 26-2-1952.

$10 \quad$ Suara Rakjat, 25-5-1957; Surabaja Pos, 26-7-1957.

11 Pewarta Surabaya, 5-2-1957; Jawa Pos, 10-4-1958.

12 Jawa Pos, 11-12-1952; Dick 2003:369; Colombijn 2010:212.

13 Jawa Pos, 10-4-1958.
} 
municipality had to concede that it only controlled about half of the 1,735 hectares of kampong land in the city and that the remainder should be formally purchased, developed, and guarded by its occupiers. ${ }^{14}$

\section{The Territorialization of Violence}

Formal government stopped at the sub-district (lingkungan) level and did not reach Surabaya's kampongs. Donald Hindley (1966:158) observed that duties below this level were performed by the Rukun Kampung Kota Surabaya (RKKS, Surabaya City Kampong Association). Established in early 1950, the RKKS collected taxes, took censuses, subsidized burials, and organized collective work and guard duties in the kampongs. ${ }^{15}$ By January 1954, the RKKs had 37 rukun kampung (RK) units under its administrative umbrella. ${ }^{16} \mathrm{~A}$ kampong consisted of several RK of ten or so rukun tetangga (RT, neighbourhoods) and each of these neighbourhoods housed several hundred residents (Peacock:1968:94). With the RKKs operating as the effective administration in the kampongs, the municipal parliament considered abolishing the sub-district as a tier of government and dealing directly with the ward and neighbourhood units of each kampong through a city-wide 'council' of kampong wards. ${ }^{17}$ The RKKS was the obvious example of such a council, but the heads of kampong wards wanted assurances that kampongs would retain their integrity as 'autonomous', 'sovereign', 'non-political', 'social and economic' units based on 'mutual selfhelp', as well as a guarantee that the RKKS would serve only as the vehicle through which they communicated with the municipal government. ${ }^{18}$ In meetings in February and October 1955 at their main office outside Dinoyo, the RKKS declared that it would uphold its original function of maintaining the autonomy and sovereignty of each kampong by only serving to help organize the administrative duties of its ward and neighbourhood heads. ${ }^{19}$ It seemed that the political position of Surabaya's kampongs was one of autonomy and that if the RKKS was to represent the kampong it would have to represent that position. In this period of popular democracy and aggressive

\footnotetext{
14 Pewarta Surabaya, 12-9-1958.

15 Hindley 1966:158; Perdamaian, 3-3-1952.

16 Jawa Pos, 21-3-1952; Colombijn 2010:217.

17 Pewarta Surabaya, 7-5-1953; Trompet Masyarakat, 29-3-1954; Java Pos, 21-3-1952, 28-1-1955, 23-2-1955.

18 Perdamaian, 2-5-1955.

19 Java Pos, 23-2-1955; Perdamaian, 7-10-1955.
} 
party-political mobilization, however, such a position would be impossible to maintain.

The army regularly accused the RKKS of being an illegitimate quasigovernment that bolstered kampong sovereignty, weakening that of the state; while the RKKS stuck by its claim that the kampong was 'an organization of the people, not the government'. ${ }^{20}$ Realizing that the guard post was the clearest expression of this sovereignty, the army supported a short-lived rival organization, Persatuan Rukun Kampong Surabaya (Association of Surabaya Kampungs), which made it a requirement of all adult males to patrol the kampong during the six weeks leading up to the national elections of mid December $1955 .{ }^{21}$ Similarly, the army instructed kampong guards to maintain order during the municipal elections of early 1958 , and to prepare for possible Dutch air strikes at the onset of the campaign against Dutch control of Irian in mid 1958. ${ }^{22}$ Although intended to increase the state's control over the guard, these initiatives gave the guard a heightened responsibility for self-defence, making it a fearsome institution that few had the courage to challenge, as was highlighted in October 1957, when a pedicab driver stabbed to death his two passengers after they ignored his fears and ordered him to enter a kampong without the permission of its guards. ${ }^{23}$ Although laws existed to prosecute the perpetrators of guard post violence, they were seldom used and the perpetrators seldom brought to justice, underscoring the widely held perception that guard post violence was an inviolable cultural institution.

On 29 January 1958, in a well-staged public event to counter the autonomy of the kampong guard, the army conducted what it termed a 'seizure of the tools of the state' by sending soldiers to kampong guard posts at 7:30 pm to help locals conduct their night guard duties. ${ }^{24}$ In June, in yet another symbolic attempt to control the guard, the army tried to standardize the sound of the guard post warning-gong by stipulating that it be beaten for thirty seconds, followed by a five second interval. Empowered by president Sukarno's 14 March 1957 declaration of a state of emergency, the army now deemed the gong to be an 'apparatus of state' along with guns and military uniforms, which they began confiscating from people. ${ }^{25}$ Pointing to the futility of these initiatives, a former guard post leader recalled, 'it was too late for top-down control because the

\footnotetext{
$20 \quad$ Trompet Masyarakat, 24-6-1958.

21 Perdamaian, 3-11-1955.

22 Jawa Pos, 31-1-1958; Pewarta Surabaya, 22-7-1958.

23 Pewarta Surabaya, 10-10-1957.

24 Jawa Pos, 31-1-1958.

25 Suara Rakjat, 23-24-5-1957; Pewarta Surabaya, 21-6-1958.
} 
army had already passed violence down to the kampong, where guarding was about enforcing respect for local traditions'.

\section{The Territorialization of Commemoration}

In November 1954, in an attempt to rid kampong-based rites of commemoration of their local distinctiveness, the department of religion established an apparatus of religious officiators (modin) in the kampongs to oversee the washing of the corpse in preparation for burial, to supervise the burial, and to lead prayer at the post-funeral slametan so as to guide residents towards the proper observance of Islam and away from so called 'bad influences' or political 'fanaticism. ${ }^{26}$ The words 'bad' and 'fanatic' referred to the RKKs, which, as outlined below, used funerals as a form of street protest. The modin would try to depoliticize funerals by standardizing them, stripping them of local cultural variations and ensuring they remained orderly when mourners made their way along the street to the public cemetery.

The standardization of commemoration threatened to replace the kampong prayer leader, who was any willing neighbour able to recite the Yasin prayer, ${ }^{27}$ with the modin, who was officially trained and endorsed by the Surabaya office of religion and who lived outside the kampong in a religious compound. ${ }^{28}$ The modin tried to impose a new supra-authority over death that families must follow in order to bury their dead. Geertz (1973:153-62) reported the consequences of this new official religious authority in 1954 in Pare, where the modin refused to officiate the death of a boy whose parents followed a small political party that mixed Marxism and Javanese spirituality. Disturbed by this creeping politicization of death, an old man grumbled to Geertz (1973:156), 'you can't even die any more; $[\ldots]$ it becomes a political problem'. The modin eventually agreed to officiate the boy's burial; but as relations between doctrinal and syncretic Muslims deteriorated further over the coming weeks, the modin ceased to register any deaths in the village, surrendering commemoration to the particular cultural stream (aliran) of the mourners (Jay 1969:371).

Death would not submit to standardization. If the modin would play a part, he would have to go with rather than against kampong commemorative tra-

\footnotetext{
26 Pewarta Surabaja, 27-11-1954, 6-12-1954.

27 The prophet instructed Muslims to recite the Yasin over the dying and in prayers for the dead (Asad 1984:673). One of the Koran's 114 surah, Yasin verses are the most commonly recited of all Koranic prayers by most Javanese Muslims. 
ditions. It was by going with Dinoyo traditions that the modin could operate there. As recalled by Agus - the giver of slametan welcome speeches mentioned above whose father played the same role in the 1950s — death was never standardized in Dinoyo. Agus held that residents kept the modin at a distance 'by only inviting him to oversee the washing of the corpse and to give a short prayer at the gravesite.' The family of the deceased and their immediate neighbours handled everything else, including the slametan, which took place for up to 7 to 40 days after death. As far as residents were concerned, they recruited the modin to suit their commemorative practices; he did not recruit them to his.

\section{The Territorialization of Politics}

To enter a kampong, one had to observe its traditions - whether by attending slametan, accepting guard-post violence, or visiting the founding father's grave to request his blessing for an activity one wanted to undertake in the kampong. The ludruk comedic troupes that regularly entered Dinoyo in the 1950s and 1960 s to entertain its residents would, for example, pay respect to the founding father by offering him a bouquet of food and flowers that was placed beside the stage, and by providing him with a short prayer and request for permission to perform. Usually sponsored by a resident as part of a slametan, ludruk troupes were the easiest way for the Partai Komunis Indonesia (PKI; Indonesian Communist Party) to enter the kampong, draw a crowd, and impart their message. Ludruk had an affinity with the kampong: its key character, the clown, was someone with whom kampong dwellers most identified; its troupe leaders were kampong people; its medium was ngoko Javanese; its stage was in or just outside the kampong; and its audience included the full range of kampong dwellers. Ludruk adapted its performances depending on its audience and invited their participation, and its central theme of nerimo extended the familiar slametan function of harmonizing emerging social tensions (see Peacock 1967, 1968). As Peacock (1968:59) observed, ludruk can more successfully attune itself to Javanese proletarians, drawing them into empathy with it, and in this way luring them into taking on the attitudes which it expresses'. Promoted by Nyoto-a senior member of the PKI's five-man Politbureau and founder of the Lembaga Kebudayaan Rakyat (LEKRA, Institute of People's Culture [est. 1950]) - folk forms like ludruk proved most appropriate in Dinoyo at grasping the kampong in terms of the geographical and genealogical proximity of its residents to the founding father (Hindley 1966:158-9, 184).

In contrast to the government's view of kampongs as fixed administrative entities, the PKI recognized them as sensory entities actualized through local 
rituals of guarding and commemoration. This recognition of kampongs as sensory entities helped the PKI see neighbourhood units as forged from the bottom up by residents rather than from the top down by government. In January 1954, for example, those in the RKks head office outside Dinoyo were aware of the difficult living conditions of Dinoyo residents and sought government help in extending and deepening Dinoyo's flood-prone drains, paving its muddy alleys, and fixing its overflowing latrines. ${ }^{29}$ Although located across the road from Dinoyo and staffed by some Dinoyo residents, the RKKs would not start documenting these demands and conveying them to the government without first bringing residents together through a slametan and ludruk performance so as to explain the purpose of their actions. ${ }^{30}$ With a growing budget deficit and struggling to pay its civil servants their salaries, the municipal government was without the funds to perform the repairs that the RKKs demanded in Dinoyo. ${ }^{31}$ However, by documenting these poor conditions and organizing Dinoyo residents to complain about them, the RKKS achieved greater political recognition for Dinoyo as a formal settlement with known leaders and defined neighbourhoods through which kampong-state relations would thereafter have to form.

Most of those leaders became quasi-officials of the RKKs through which the PKI now increasingly worked to muster political support for the 1955 national elections. In exchange for PKI support, residents pinned the colours, signs, and symbols of communism to their alley walls and house fronts. In kampong Kedungturi, for example, the RKKS provided red lampshades for residents to hang over the front light outside the door of their homes each night from 1 to 3 May in celebration of May Day $1955 .{ }^{32}$ Next to the city's big industrial estate in Ngagel kampong, where the RKKs had helped residents resist the demolition of their homes, alleyways were renamed after communist heroes. Through symbols in exchange for political support, kampong residents had begun to achieve recognition for their kampongs as formal settlements endorsed by PKI. Kampongs supportive of the PKI were mostly located in the densely settled, lower-income parts of Surabaya, particularly across a belt of settlements in the southern half of the city that included Dinoyo. Results from the 1955 national election reveal that the PKI won two to five times as many votes in these areas than Surabaya's next strongest parties, the Nahdlatul Ulama (NU) and Partai Nasionalis Indonesia (PNI; Indonesian Nationalist Party). ${ }^{33}$

\footnotetext{
29 Trompet Masyarakat, 8-6-1954.

30 Eko, personal communication, 10-1-2010.

31 Trompet Masyarakat, 14-5-1953; Pewarta Surabaya, 7-10-1954, 30-10-1954.

32 Perdamaian, 2-5-1955.

33 Perdamaian, 3-10-1955.
} 
The army and municipality viewed the recolouring and renaming of kampongs as evidence that society was rejecting the sovereignty of the state. Indeed, since the Dinoyo initiative of early 1954, the RKKs had been making public speeches that deemed kampong land and administrative apparatus the possession of occupants, not the state; they also proclaimed that neither the municipality nor the army had the right to outlaw squatting or evict squatters. The RKKs held that the municipality should help kampong residents formalize their tenure and improve their neighbourhoods, but the municipality's lack of money and manpower to do so weakened its claim on the kampong, strengthening that of the RKKs. ${ }^{34}$ For the army, the RKKS was a quasi-state that was obstructing the formal state. For the PKI, the RKKS was simply fighting for the sovereignty of the kampong and mobilizing people for bottom-up development. ${ }^{35}$ This conflict played out in July 1954, when the RK Ks helped residents of Ngaglik kampong reject a municipal letter instructing them to demolish their homes or be fined. The R KKS reasoned that the kampong administration and its leaders had a right to resist the instruction because neither they nor their kampong were part of the state apparatus. The police were caught in this impasse between kampong and state, unsure whether the kampong leaders they held in their custody for rejecting the government letter and the 44 residents issued with fines for refusing to comply with the demolition were guilty or whether they should have charges against them dropped. ${ }^{36}$

The assertion of occupancy rights was so effective in giving squatters a quasilegal claim to land that assertions began to be made over land claimed by Islamic organizations and the army. By mid May 1956, riding high on its success in the previous year's national elections, ${ }^{37}$ the PKI declared the demolition of squatter homes illegal and resistance to it rightful. ${ }^{38}$ In September 1957, squatters around the mosque at Kembang Kuning used the help of the PKI to take the mosque leader to court for trying to evict them (Basundoro 2013:294). Although held up in court and unresolved, the case highlighted that occupancy was a force that could challenge the city's Islamic clergy. About a year later, it became clear that occupancy was a force that could challenge the army, when over 1,700 squatters on the city's north-western fringe formed the Delegasi Warga

\footnotetext{
34 Jawa Pos, 20-2-1953, 25-2-1953; Basundoro 2013:300.

35 Trompet Masyarakat, 16-5-1953.

36 Pewarta Surabaja, 8-10-1954.

37 The PKI won 155,000 votes and 18 seats in Surabaya's municipal assembly, or almost two and a half times the votes and seats of the Nahdlatul Ulama and five times that of the PNI (Surabaja Pos, 10-8-1957).

$38 \quad$ Surabaja Pos, 14-5-1956.
} 
Kampong Dupak Masigit (Delegation of Kampung Dupak Masigit Residents) to request from the government the right of rental over land claimed by the army. The army responded by pinning signs throughout the kampong declaring that the area belonged to them, but residents reacted by allowing squatting and shack building to intensify, making it too politically difficult for the army to level what was now a large and densely populated kampong (Basundoro 2013:191-3). Such cases of successful resistance occurred across the city during the 1950 s and early 1960s, demonstrating that the moral and often legal right of occupancy was powerful enough to prevent the state, the clergy, and the army from asserting their will over Surabaya's kampong population.

The death or injury of a kampong resident who defended their right of occupancy gave that right further moral force. In one such incident in April 1956 in the pro-PKI Ngagel neighbourhood, residents halted the government's planned demolition of 300 homes after a wall collapsed during the demolition, injuring a girl and sending 1,00o residents to the governor's office in vocal protest (Colombijn 2010:220). In a similar incident a month later, 3,000 residents of nearby kampong Pakis surrounded a demolition crew, lynched the supervisor, and lynched a policeman who had shot dead a man and young girl in the protesting crowd. The man and girl were buried two days later at the Ngagel cemetery amidst thousands of mourners in an emotive funeral procession that made the municipality realize that it was impossible to eradicate squatting, forcing them to announce on 5 May $195^{6}$ the suspension of all squatter evictions in the city. ${ }^{39}$ No longer was kampong sovereignty simply broadcast via its graveyard gatekeepers or slametan welcome speakers to a group of newcomers inside the city's hidden alleyways. After these deaths, it was broadcast to the public via large funeral processions that informed a popular counter-politics of land to its occupiers - a counter-politics pitched at those police, soldiers, and government officials who tried to prevent it.

\section{The Disunited Dead}

The occupation of land and the burial of one's kin there asserted citizenship through soil so to speak, while the dispossession of people from land and exhumation of one's dead kin from it revoked that citizenship. By 1952, squatters had taken over thirty graveyards in the city, digging out the corpses, tossing them aside, demolishing the tombs and using them as foundations for their 
shacks. ${ }^{40}$ Unparalleled in other Indonesian cities, this displacement of the dead by the living was typified by the take-over of a Chinese graveyard at Banyu Urip, where squatters had built around 800 shacks by the end of the 1950s and established neighbourhood administrative structures under the authority of informal leaders who oversaw the subdivision of graveyard land into plots of 5 by 10 metres (Basundoro 2013:246-7, 251; Silas 1988:18). Ornate and in strategic locations near roads, hillsides, and rivers where the feng shui was good, and on large private estates, Chinese graves symbolized to many Indonesians the conquest of space by a foreign ethnic minority, ${ }^{41}$ many of whom claimed Chinese rather than Indonesian citizenship, enjoyed the privileged status of 'foreign Orientals' under the Dutch, and were accused of supporting Dutch reoccupation of the city during the revolution and occupying the homes of fleeing Indonesians (Basundoro 2013:184-5; Husain 2015:327; Frederick 1989:281; Palmos 2011:2978). In response to Chinese requests for the protection of their dead, the police escorted Chinese funeral processions and fined or jailed those who obstructed Chinese burials or destroyed Chinese graves. By doing so the police seemingly reinforced the privileged status given to those whom many Javanese considered to be undeserving foreigners who existed outside the Javanese status system as not yet human (durung wong) or to be uncultured children who could be treated with impunity (Husain 2015:332; Keeler 1987:35).

In March 1958, when the municipality managed to close seven Chinese graveyards to prevent their occupation, demonstrating squatters promptly reoccupied the sites and, as they had done in Banyu Urip, instructed Chinese families to bury their dead elsewhere, while denying them access to the graves of those who were already buried there. ${ }^{42}$ By the close of the decade, the squatters had prevailed, turning most of Surabaya's Chinese graveyards into kampongs and sending a powerful message to the municipality that its best efforts to protect Chinese graves had failed (Husain 2015:336; Colombijn 2010:222). As Sarkawi Husain (2015:333, 339) notes, backed by the PKI and facing a popularly elected municipal parliament that had far less power than its

40 Jawa Post, 11-12-1952; Basundoro 2013:246, 248.

41 Largely as a result of their flight from the republican-controlled hinterland to the safety of Dutch-controlled Surabaya between 1947 and 1949, and (like Indonesians more generally) their move to Surabaya to escape the depressed countryside, the number of ethnic Chinese in the city more than doubled from 47,884 in 1940 to $109,55^{1}$ in 1951. This percentage increase was similar to that of the pribumi (308,000 to 703,477), making the ethnic Chinese a sizeable and numerically dominant ethnic minority after Independence (see tables in Basundoro 2013:35, 45).

Pewarta Surabaja, 14-3-1958; Basundoro 2013:247; Husain 2015:331-2. 
Dutch or Japanese predecessors, the squatters 'dared to resist'. This increasing power of the periphery was writ large on the national stage by the mid 1950s, with armed rebellions in Sulawesi and Sumatra and the rise of the PKI, whose cadres, note Jay $(1969: 424,422)$, 'took some of the prestige of government officials' and 'undercut the [central government] monopoly' in the kampongs. The more apparent and immediate expression of the power of the periphery, however, was simply the demographic dominance of the poor newcomer, which persisted into the 1960 s as low-skilled rural migrants continued to account for most of Surabaya's population increase and continued to cram into the city's kampongs (McCutcheon 1977:92-119, 1978:82). Peacock (1968:18) depicted these kampongs as typically located near graveyards and as 'clusters of bamboo huts and small cement houses' accessed by a 'tortuous and extensive network of alleyways'. Demographically, aesthetically, and politically, the slum-dwelling newcomer of Surabaya's low-income kampong settlements was a seemingly intractable, if not dominant, human presence in the city. To gain control over the city and bolster the power of the centre, the army would have to eliminate the newcomer's potent power of occupation and the political project that supported him.

By late October 1965, as mutilated corpses washed up on the banks of the Brantas river that flowed into Surabaya, the right to act with impunity against a people and deny them the commemoration of their dead had become a popular political strategy, this time aimed not at the Chinese but at the communists. Dinoyo residents saw the corpses as they washed up on the banks of the river bordering their kampong. Many were headless and had washed up there from down river in the hinterlands, where the killing was more intense. Dinoyo people had seen corpses along the river during the Battle of Surabaya in 1945, but the corpses of 1965 were different because they could not be taken away and buried. The deaths of 1945 and 1965 occurred during the wet season, when soil was soft and easy to dig, but only during 1945 did people take advantage of the fields on the eastern side of the river to dig graves and achieve the basic Islamic requirement of a prompt burial. ${ }^{43}$ In 1965 , they feared that burying a corpse showed sympathy to the communist and they knew of people who had been arrested for doing so (Dick 2003:103; Hearman 2012:124). By early December, with the stench from the rotting corpses unbearable and the river water and fish contaminated, the military ordered a clean up, but few people complied. A man who lived behind the Banyu Urip canal, where corpses were piling up, explained his reluctance to follow military instructions and retrieve them: 
An instruction eventually came down do retrieve and bury the corpses, which stunk and were contaminating the rivers and canals. But where were we to bury them? Lack of places to bury them aside, we didn't know who they were, who their families were and, therefore, where they should be buried. They weren't from here and were unknown to us. What were we to do? We pushed them back into the canal to be carried away by the current. ${ }^{44}$

In 1945, most of the corpses were of people who lived in Surabaya, enabling them to be promptly repatriated to local burial grounds and commemorated. Repatriation and burial allowed the realization of the Javanese ideal of the potent power of the unity of the dead and the living through death - a unity denied to the victims of 1965 . Coming from afar and unknown, the corpses of the supposed communists could not be repatriated and were left literally dismembered and cut off from society.

\section{The Relocation of Death}

The purges failed to wrest the control of death from society. The army had urged community participation in the murders and Indonesia's largest Islamic organization, NU, had deemed them a religious duty, turning President Sukarno's oft-espoused 'revolution from within' into a shocking crescendo as people put their revolutionary right to define insiders and outsiders into murderous action. Shocked by the violence, president Sukarno drew attention to the corpses it produced, lamenting that they 'were left under trees, beside rivers, thrown like the corpses of dead dogs'. He appealed to $\mathrm{NU}$ supporters, the main perpetrators, to at least bury those they killed, asking them 'not to neglect the corpses, not to make the orphans more miserable' (in Crouch 1978:157). By late December, a little over two months after the head of Surabaya's district military command organized a mass anti-communist rally that marked the onset of the purge there, tens of thousands of people had been murdered in Surabaya and its hinterland in an intensity of killing that threatened to depopulate whole neighbourhoods if not stopped. ${ }^{45}$ With the communists murdered, imprisoned, or in hiding, the army had achieved its end, but not without dangerously empowering society with a right to violence.

44 Anonymous, personal communication, 11-8-2015.

45 Surabaja Post, 18-10-65; 'Report from East Java' 1986:140; Setiyawan and Husain 2011:303; Hearman 2012:110. 
Those most empowered were NU supporters, who an American consulate official in Surabaya described as by far the largest, most youthful, most fearsome, and most well-resourced group in the city (Walkin 1969). In mid 1966, the new head of the East Java military command followed the new army line established in January by his interim predecessor, who had declared that 'wild deeds outside the law' will be prosecuted and that 'if necessary individuals who do not obey orders from the authorities will be shot dead' (Hearman 2012:133; Crouch 1978:154). These instructions and others like them by army commanders in Malang, Kediri, and nearby towns were aimed at the $\mathrm{NU}$ and at extirpating its right to violence. Under Indonesia's new leader and now Indonesian president General Soeharto the army turned against NU, replacing it with modernists in the Departemen Agama (Department of Religion) and dissolving its political party (Fealy 1998:359). Hasyim Asyari, an NU militia leader during the killings, felt betrayed by Soeharto's New Order, stating:

Things were worse [during the New Order period] than during the PKI period [...] [All government officials] from the president to the neighbourhood head had to keep tabs on NU members, restricting our freedom. Our leaders were summoned to sub-district military offices for interrogation [...] I could cry when I think about it because my underlings were beaten [during the interrogations]. The longer things went on [under the New Order], the harder things got for us, the longer things went on, the more we suffered. Even though NU was the most active [in eliminating the $\mathrm{PKI}]$, we were the ones who were muted. ${ }^{46}$

In official discourse, the only victims worthy of sympathy were six generals and a lieutenant. These men had been killed by soldiers led by the elite Presidential Palace Guard, or Cakrabirawa Regiment, in an early morning strike at their homes on 1 October-a strike the guards claimed was carried out to stop the generals from staging a right-wing coup against president Sukarno. Three days later, after promptly capturing the renegade soldiers and restoring control, a young Major General Soeharto and his men of the army's new Kostrad (Komando Cadangan Strategis Angatan Darat: Kostrad: Army Strategic Reserve Command) force summoned cameramen and journalists to Halim air base in Southeast Jakarta to document the exhumation of the corpses of the dead generals from a disused well. Military-controlled newspapers reported that PKI cadres had stood by at the air base while women from PKI's Gerwani,

46 Interviewed by Vannessa Hearman, 10-2-2009. 
or Gerakan Wanita Indonesia (Indonesian Women's Movement), mutilated the genitals of the dead generals. Although proven to be a fabrication, this tale of genital mutilation created a powerful story of direct and sadistic communist involvement in the murders. The dead generals were commemorated in a great public funeral the next day, main streets in towns across the archipelago were named after them, and the well at Halim was made into an anti-communist monument. ${ }^{47}$ The events in Jakarta that took place between 1 and 5 October had turned Indonesia's army officers from a maligned group, accused of corruptly serving their own interests, to heroes now deemed guardians of the people (Crouch 1975:521, 522; Castles 1967:81; McDonald 1980:30). Suddenly dated were Dan Lev's (1963:329, 341) observations from two years earlier that people 'wanted the army to withdraw from sight' and that the PKI appeared by comparison a 'tower of strength amidst chaos'.

The New Order now determined the nation's heroes. Soeharto made this point on Hari Pahlawan (Heroes Day) 1974 through the reburial of an unidentified soldier who had died on the first day of the Battle of Surabaya in 1945. In the early days of the battle, the names of fallen members of the police, army, and educated youth were listed in the newspaper upon their burial in the city's hero's cemetery for fallen soldiers. ${ }^{48}$ The anonymous dead were buried in fields where the soil was soft, while the known dead were buried in kampong graveyards, known only to their families and graveyard gatekeepers. Unlike those buried by the state in heroes' cemeteries, those buried by kampong residents in fields or kampong graveyards were locally commemorated. The reburial of the unidentified soldier in 1974 achieved a ceremonial demotion of the locally commemorated, establishing what Klaus Schreiner (2002:199) termed 'a new ritual hierarchy among the sacred sites, depriving Surabaya and other historic locales of their symbolic power'. This new hierarchy shifted the topogeny of sainthood from founding father and kampong to soldier and state.

\section{The Repatriated Corpse}

The saints on its periphery were now a threat to the new ritual hierarchy established by the New Order. This was highlighted on 3 February 1982, when the family of revolutionary hero Bung Tomo carried out his wish to be buried

\footnotetext{
47 The events referred to in this paragraph are documented in Indonesian newspapers during those weeks and in numerous scholarly accounts, among them Lev 1966, Anderson and McVey 1971, Crouch 1978, and Roosa 2006.

48 Soeara Rakjat, 4-10-1945, 5-10-1945, 31-10-1945; Siaran Kilat, 3-11-1945, 4-11-1945.
} 
among commoners in the public cemetery at Ngagel, rather than among those endorsed by the state at the nearby hero's cemetery. Unlike state-endorsed saints, who were removed from society, those on its periphery remained within society as a 'quiescent' power against that of the state (Keeler 1987:85).

In what seemed his final declaration against the state's control of death, Bung Tomo echoed society. By the time of his burial in early 1982, the state appeared to be losing control of society, which was in the grip of a crime wave depicted through newspaper images of bandits robbing people without police in sight and regular stories of violent crime inflicted upon innocent civilians. ${ }^{49}$ Underpinning the law-and- order crisis was a demographic crisis. By the early198 os, the population of Surabaya's inner-city kampongs was only about two thirds larger than what it had been in the late 196os, stressing toilets and wells and increasing the risk of water-born diseases for a people whose health was already compromised by poor nutrition after a severe drought in hinterland food-growing regions followed a reduction in subsidies on basic foodstuffs. ${ }^{50}$ People were hungry and struggling to find work as population growth far outpaced job growth in a stagnating economy that was trying to diversify away from a dependence on oil exports (Dick 1982; McCawley 1983; Arndt 1983). Those suffering most were Surabaya's recent migrants, the majority of them young men from the countryside who mingled at bus stations, markets, and along streets, looking for work unloading trucks, selling bus tickets, busking, begging, and joining 'Massa 33', the notorious citywide gang that claimed 50,000 members. ${ }^{51}$

Adding to these security concerns was the release over the previous four years, following pressure from Amnesty International, of most of Indonesia's communist prisoners. Major General Sasono of Indonesia's all powerful internal security agency, Komando Operasi Pemulihan Keamanan dan Ketertiban (коркамтів, Command for the Restoration of Security and Order), warned that these prisoners were returning to a society that 'lacked the organizational capacity' in the kampong to control them and which had 'lost its fear' of them. ${ }^{52}$ To protect against criminals and communists, the police began to monitor the kampong guard by visiting guard posts each night to gather information on crime and instruct guards in how to deal with it. Purportedly done to control vigilantism as part of a new integrated security programme abbreviated

\footnotetext{
49 Surabaya Post, 3-7-1982, 15-7-1982; Tempo, 3-4-1982.

50 Surabaya dalam angka 1998:70; Arndt 1983; McCawley 1983.

$51 \quad$ Surabaya dalam angka 1984, 5:23; Mappalahere 1983:52, 59; Peters 2013:91.

$5^{2}$ Surabaya Post, 1-7-1982.
} 
Siskamling (Sistim Keamanan Lingkungan, Local Security System), which coordinated the way local groups managed crime, this police monitoring of the guard instead gave guards the idea that the state endorsed their violence. ${ }^{53}$ A Surabaya Post photographer captured the new mood with a photo of a group of men at a guard post confidently wielding clubs, sickles, bamboo spears, iron bars, and torches before a table with glasses of coffee to keep them alert. ${ }^{54}$ Despite its empowerment, the guard proved ineffective as crime worsened, most notably in September, when criminals murdered the family of an East Javanese military commander (Barker 1999:252). Already sceptical of the method of passing violence down to society through the kampong guard, senior army officers, including president Soeharto, endorsed a shift to extrajudicial killing by soldiers and police as the preferred method of crime control (Bourchier 1990:183).

Known by the acronym Petrus (penembakan misterius, mysterious shootings) due to the shadowy circumstances that left the corpses of suspected criminals lying along riverbanks and roadsides, the killings began in early 1983. By the end of the year hundreds and perhaps thousands of lives had been taken, in what president Soeharto later declared was a deliberate strategy of 'shock therapy' aimed at deterring criminals and re-establishing the authority of the state (Bourchier 1990:185; Suharto 1989:390, in Elson 2001:237). Unlike the corpses of 1965 , which people feared to retrieve, those of 1982 had money placed in their pockets by their executioners along with a letter instructing the finder to put the money towards a funeral. A former communist prisoner who was returned to society at the time recalled being struck by this contrast, stating: 'I was taken from society when the army threatened those who tried to retrieve corpses and returned to society when they encouraged people to retrieve them. ${ }^{, 55}$ Another eyewitness, also taken by the contrast between the corpses he saw in and along the river in 1965 and those of 1983 , stated:

I remember seeing corpses dumped near the kampong. It seemed pretty clear that this was done so that the [victim's] relatives or neighbours could come and pick them up and take them away to be buried. In the [clothes'] pockets of the victims there was always some money and a letter stating that the money had to be put towards a burial and a slametan for the victim [...] It was no doubt an instruction from the top

55 Anonymous, personal communication, 24-2-2014. 
because it happened everywhere. Most people I know, and me included, found these letters and this money each time we went to check and retrieve a corpse. Unlike in 1965 , when it was a moral responsibility to leave the corpses there, in 1983 it was a moral responsibility to take them away! ${ }^{56}$

Designed to enable the repatriation of the corpse, this novel method of funding its burial and commemoration marked the state's reclaiming of control over death.

This state-supported repatriation of the dead was linked to the tying of the population to kampongs through the kampong improvement programmes or KIP, which began in Surabaya's poor inner-city neighbourhoods around the same time. As part of KIP, the municipality used central government block grants and technical assistance to help residents improve toilet blocks, mosques, homes, and alleyways in their kampongs (Peters 2013:80-2). Taking over from where the fated RK Ks had left off almost twenty years before, teams of civil-servant and university student surveyors mapped Dinoyo and counted its population, increasing cadastral capacity in the kampong, expanding its population of taxpayers, and bolstering the ability of the neighbourhood head to collect a monthly tax from each identified household (Peters 2013:76-82; Silas $1988: 4,31$ ). Part of the monthly tax revived the old funeral subsidy once organized by the RKKS, which now gave residents the equivalent of about three days' salary to help pay for funeral expenses and the food given to guests at the postfuneral slametan. Although miniscule compared to the contributions in money and kind by neighbours at a slametan, the revived funeral subsidy was part of the state's attempt to return death to the kampong.

\section{The Rebellious Corpse}

Petrus and KIP formed a two-pronged approach that established the people's control of death in the kampong and the state's control of it on the street. The people of Dinoyo fear the street and the adjacent river, which they have nicknamed the 'River of Blood' because of all the corpses that have washed up on its banks since 1945. Kampong men would hurry to the river whenever a corpse appeared there, lining the bank and climbing trees to yell updates on the corpse's position to friends below. Such events were common and evidence

56 Anonymous, personal communication, 16-9-2015. 
of James Siegel's (1998:110) point that corpses had become 'attractions'. They particularly attracted young men, who saw in them a reflection of what Claudio Lomnitz (2008:379) considered oneself, or one's fate as a person who suffers an unnatural death at the hands of others and away from home.

That fate was expressed through the silent suffering of kampong mothers, who had not spoken out since the banning of Gerwani in 1965. One of those mothers was Bu Neng, a once active Gerwani member, who had lost a husband and two sons to what she and neighbours termed masuk angin (wind/draft that enters the body making it ill), caused by too much time spent on the street, exposed to the elements. On a night in mid May 1998, Bu Neng's screams broke through the silence of the night, and it seemed the silence of three decades of New Order rule, as she lay on the dirt floor of her rented shack. Bu Neng was screaming and spitting while her three surviving sons tried to restrain her during a hysterical fit. Bu Neng's third such fit in two months was caused, according to neighbours, by the trauma of the deaths of her husband and sons having weakened her to the point where she was unable to prevent her emotional pain from manifesting itself physically.

Her screams were an early sign of what Michael Taussig (1989:8) termed that moment when the 'abnormality of the normality' of state violence occurred to people. They were an echo of people's collective horror after watching television broadcasts of the charred corpses of two hundred people, burned to death in an East Jakartan mall by rampaging men widely suspected of having operated under the instruction of rogue army officers. ${ }^{57}$ Now a potent symbol of the people as victims of state violence, the corpses had the power to enunciate an otherwise unstated state-society relationship that a resident of the kampong next to the burned-out mall summed up in terms of 'the corpse as victim, the state as perpetrator' (mayatnya korban, pemerintah pelakunya). ${ }^{58}$ The corpse had been a key site through which the New Order projected its power since 1965. A barometer of that power, the corpse was now beyond the state's control, as evidenced one sultry afternoon when several men from Dinoyo rallied together to salvage the body of a man trapped in his car after it crashed into the river. Hundreds of kampong men gathered at the river's edge, blocking the access of two policemen, who could only stand and watch as the rescuers tied lengths of rope together into a fifty metre line, tied one end to a tree, the other to the man's arm and dragged his lifeless body to the riverbank for it to be picked up by his family. These men had played a small part in helping to repatriate the

$57 \quad$ Kompas Online, 16-5-1998.

$5^{8}$ Anonymous, personal communication, 26-7-2013. 
deceased to his kampong; a part they and other men from Dinoyo would play again over the coming months whenever they spotted a corpse in the river. It was a part they would not have dared to take at the beginning of the New Order, but one that they took with great determination at its end.

\section{Control of the Slametan}

As the state lost control of death on the street, it tried to gain control of it in the kampong. In June 1998, in the wake of Suharto's resignation, the municipality issued an instruction to neighbourhood heads to stop allowing newcomers access to the funeral subsidy. Sitting before the eight neighbourhood heads of his ward, the ward head explained:

Many people who die within the kampong have lived here for many years and are well known to everybody, but are not registered residents of the kampong. We have continued to allow them to access the funeral allowance without questioning their residency status. We have just assumed that they are legitimate residents with permits to reside in the kampong. This can't go on. We don't have enough money for everyone, quite a lot of people have died lately and we have used up a lot of the money; if more die we will have trouble giving funeral money to those entitled to it. ${ }^{59}$

About a year after the above instruction, the municipality issued another that required the family of the deceased to give notification of the death to their neighbourhood head, who then distributed name cards (kartu keluarga) to the head of every household in the neighbourhood. Only those registered as living in Dinoyo received name cards, which they were to use as guest passes to the slametan. Receipt of these cards served as formal notification to household members of the death of a neighbour, taking the place of the traditional beating of the warning gong by a young male relative of the deceased. Unlike the sound of the warning gong, which was meant for all, the name cards were meant to exclude unofficial residents by denying them official notification of the death. Neighbourhood was now to be defined by the distance of documents rather than the proximity of being within ear-shot, demanding that only administratively legal kampong citizens could participate. 


\section{Conclusion}

The name card intervention failed. Neighbourhoods continued to form around the sensory community of the warning gong, rendering the name cards a redundant symbol of the state's ineffective intervention into death. By 2015, the neighbourhood official had long since given up issuing name cards, which sat in a dusty box in the neighbourhood guard post, unlikely to be used again. Slametan took place almost every day in the neighbourhood and it was impossible for him to keep track of each and every one of them. One such slametan took place on 16 August 2015 to commemorate the fortieth day of death of Eko, an old man who had fought as a soldier in the revolution and who had once recalled for me how slametan were staged for him and others upon their return to Surabaya after the granting of independence in December 1949. Assisted by a collective prayer for the dead by all in attendance, the event marked Eko's final ascent into the afterlife. Occurring only a day before the seventieth anniversary of Sukarno's 17 August 1945 Declaration of Independence, for those present it also served as a reminder of how the past connects them to the present through a now deceased man, whose life as a freedom fighter, labourer, neighbour, friend, father, and grandfather coalesces with them as they impart prayers, share food, and stay up throughout the night to remember him, as he had done with them on so many occasions while living. Those there to remember him included old friends and relatives from beyond the kampong as well as decades-long neighbours, who all shared time over their lives in the alley outside his home, where they had become well accustomed to the local prayers and practices through which ancestors were commemorated. Among them were those who had fought in the revolution, been persecuted during the purge, evaded the police during Petrus, and watched as Soeharto's order unfolded into the democratic Indonesia they now occupied. For all of them, the posthumous bond sanctified in the slametan linked living and dead and neighbour and kin into an ideal inclusive 'Us' that gave people an indispensible feeling of collective harmony and homeostasis, which was of great value in a world where death was otherwise used to divide and exclude. In the seventy years of struggle for control over death and its commemoration, the slametan held its ground against this politics of exclusion, enabling the politically muted kampong residents of Surabaya to maintain their inclusive traditions and manage, on their own terms, the political and demographic changes that have rippled through the city since its independence. 


\section{References}

Akhudiat. (2008). Masuk kampung keluar kampung: Surabaya kilas balik. Surabaya: Henk Publica.

Anderson, B. and R. McVey. (1971). A preliminary analysis of the October 1,1965 coup in Indonesia. Ithaca: Cornell University Press Southeast Asia Program.

Arndt, H. (1983). 'Survey of recent developments', Bulletin of Indonesian Economic Studies 19-2:1-26.

Asad, M. (1984). The message of the Quran. Gibraltar: Dar Al-Andalus.

Barker, J. (1999). The tattoo and the fingerprint: Crime and security in an Indonesian city. [PhD thesis, Cornell University, Ithaca, NY.]

Barker, J. (2001). 'State of fear: Controlling the criminal contagion in Suharto's New Order', in B. Anderson (ed.), Violence and the state in Suharto's Indonesia. Ithaca: Cornel Southeast Asia Program Publications.

Basundoro, P. (2009). Dua kota tiga zaman: Surabaya dan Malang sejak kolonial sampai kemerdekaan. Yogyakarta: Ombak.

Basundoro, P. (2012). Sejarah pemerintah kota Surabaya: Sejak masa colonial sampai masa reformasi, 19o6-2012. Yogyakarta: Ombak.

Basundoro, P. (2013). Merebut ruang kota: Aksi rakyat miskin kota Surabaya 19oo-196os. Tangerang: Marjin Kiri.

Beatty, A. (1999). Varieties of Javanese religion: An anthropological account. Cambridge: Cambridge University Press.

Block, M. (1971). Placing the dead: Tombs, ancestral villages and kinship organization in Madagascar. New York: Seminar Press.

Bourchier, D. (1990). 'Crime, law and state authority in Indonesia', in: A. Budiman (ed.), Crime and civil society in Indonesia. Clayton: Monash Asia Institute.

Castles, L. (1967). ‘The fate of the private entrepreneur', in: T. Tan(ed.), Sukarno's guided Indonesia. Brisbane: Jacaranda Press.

Colombijn, F. (2010). Under construction: The politics of urban space and housing during the decolonization of Indonesa, 1930-196o. Leiden: KITLV Press.

Crouch, H. (1975). 'Generals and business in Indonesia', Pacific Affairs 48-4:519-40.

Crouch, H. (1978). The army and politics in Indonesia. Ithaca: Cornell University Press.

Dick, H. (1982). 'Survey of recent developments', Bulletin of Indonesian Economic Studies 18-1:1-38.

Dick, H. (2003). Surabaya, city of work: A socio-economic history, 1900-200o. Athens: Ohio University Press.

Elson, R.E. (2001). Suharto: A political biography. Cambridge: Cambridge University Press.

Errington, S. (1987). 'Incestuous twins and the house societies of Insular Southeast Asia', Cultural Anthropology 2-4:403-44. 
Faber, G.H. von (1934). Nieuw Soerabaia: De geschiedenis van Indië's voornaamste koopstad in de eerste kwarteeuw sedert hare instelling, 19o6-1931. Surabaya: Van Ingen.

Fealy, G. (1998). Ijtihad politik ulama: Sejarah NU 1952-1967. Yogyakarta: LkiS.

Fox, J. (1997). 'Place and landscape in comparative Austronesian perspective', in J. Fox (ed.), The poetic power of place: Comparative perspectives on Austronesian ideas of locality. Canberra: ANU-Epress.

Fox, J. (2002). 'Interpreting the historical significance of tombs and chronicles in contemporary Java', in: H. Chambert-Loir and A. Reid (eds), The potent dead: Ancestors, saints and heroes in contemporary Indonesia. Honolulu: University of Hawai' $\mathrm{i}$ Press.

Frederick, W.H. (1978). Indonesian Urban Society in Transition: Surabaya 1926-1946. [PhD thesis, University of Hawaii, Honolulu, Ann Arbor, Michigan. University Microfilms International, 1981.]

Frederick, W.H. (1989). Visions and heat: The making of the Indonesian revolution. Athens: Ohio University Press.

Geertz, C. (1960). The religion ofJava. Chicago: University of Chicago Press.

Geertz, C. (1963). Peddlers and princes: Social development and economic change in two Indonesian towns. Chicago. The University of Chicago Press.

Geertz, C. (1973). 'Ritual and social change: A Javanese example', in C. Geertz, The interpretation of cultures. New York: Basic Books.

Harding, V. (1992). 'Burial choice and burial location in later medieval London', in: S. Bassett (ed.), Death in towns: Urban responses to the dying and the dead, 1000-1600. Leicester, UK: Leicester University Press.

Hearman, V. (2012). Dismantling the fortress: East Java and the transition to Suharto's New Order regime, 1965-1968. [PhD thesis, University of Melbourne.]

Heemstra, J. (1940). 'Particuliere landerijen in en om Soerabaja', Koloniaal Tijdschrift 29:48-62.

Heffner, R. (1985). Hindu Javanese: Tengger tradition and Islam. New Jersey: Princeton University Press.

Hindley, D. (1966). The Communist Party in Indonesia, 1951-1963. Los Angeles: University of California Press.

Husain, S. (2015). 'Chinese cemeteries as symbols of sacred space, control, conflict and negotiation in Surabaya', in F. Colombijn and J. Coté (eds), Cars, conduits, and kampongs: The modernization of the Indonesian city, 1920-196o. Leiden: Brill.

Jay, R. (1969). Javanese villagers: Social relations in rural Modjokuto. Cambridge, MA: MIT Press.

Kartodirdjo, S. (1973). Protest Movements in Rural Java: A Study of Agrarian Unrest in the Nineteenth and Early Twentieth Centuries in Java, Singapore, Oxford University Press.

Keeler, W. (1987). Javanese shadow plays, Javanese selves. New Jersey: Princeton University Press. 
Khan, M.Z. (trans.) (1975). Gardens of the righteous: Riyadh as-Salihin of Imam Nawawi. London: Curzon Press.

Lev, D. (1963). 'The Political Role of the Army in Indonesia', Pacific Affairs 36-4: 349-64.

Lev, D. (1966). 'Indonesia 1965: The year of the coup', Asian Survey 6-2:103-10.

Lomnitz, C. (2008). Death and the idea of Mexico. New York: Zone Books.

Mappalahere, F. (1983). 'Organisasi massa Tiga Tiga: Studi kasus pengamanan swasta di Surabaya', Widyapura 2-4:50-64.

McCawley, P. (1983). 'Survey of recent developments', Bulletin of Indonesian Economic Studies 19-1:1-31.

McCutcheon, L. (1977). Migrant adjustment in Surabaya, Indonesia. [PhD thesis, Brown University, Providence. Ann Arbor, Michigan. University Microfilms International, 1979.]

McCutcheon, L. (1978). 'Occupation and housing adjustments of migrants to Surabaya, Indonesia: The case of a second city', International Migration Review 12-1: 82-92.

McDonald, H. (1980). Suharto's Indonesia. Melbourne: Fontana.

Moertono, S. (2009 [1968]). State and statecraft in Old Java: A study of the later Mataram period, 16th to 19th century. Singapore: Equinox Publishing.

Palmos, F. (2011). Surabaya 1945: Sacred territory; Revolutionary Surabaya as the birthplace of Indonesian independence. [PhD thesis, University of Western Australia, Perth.]

Peacock, J. (1967). 'Comedy and centralisation in Java: The ludruk plays', The Journal of American Folklore 80-318:345-56.

Peacock, J. (1968). Rites of modernisation: Symbolic and social aspects of Indonesian proletarian drama. Chicago: Chicago University Press.

Peters, R. (2013). Surabaya, 1945-2010: Neighbourhood, state and economy in Indonesia's city of struggle. Singapore: NUS.

'Report from East Java' (1986). 'Report from East Java', Indonesia 41 (April):135-50.

Roosa, J. (2006). Pretext for mass murder: The zoth September Movement and Suharto's coup d'état in Indonesia. Madison: University of Wisconsin Press.

Schreiner, K. (2002). 'National ancestors: The ritual construction of nationhood', in: H. Chambert-Loir and A. Reid (eds), The potent dead: Ancestors, saints and heroes in contemporary Indonesia. Honolulu: University of Hawai'i Press.

Setiyawan, D. and S. Husain. (2011). 'The urban kampung in rural space: Change, continuity and conflict in peri-urban Surabaya', in: J. Khusyairi and L. Rabani (eds), Kampung perkotaan: Kajian historis-anthropologis atas kesenjangan sosial dan ruang kota. Yogyakarta: New Elmatera.

Siegel, J. (1983). 'Images and odors in Javanese practices surrounding death', Indonesia 36 (October):1-14.

Siegel, J. (1986). Solo in the New Order: Language and hierarchy in an Indonesian city. Princeton: Princeton University Press. 
Siegel, J. (1998). A new criminal type in Jakarta: Counter-revolution today. Durham: Duke University Press.

Siegel, J. (2000). 'Varieties of Javanese violence', Indonesia 69 (April):193-201.

Silas, J. (1988). The kampungs of Surabaya. Surabaya: Municipal Government of Surabaya.

Surabaya dalam angka. (1984). Surabaya dalam angka. Surabaya: Surabaya Statistics Office.

Surabaya dalam angka. (1998). Surabaya dalam angka. Surabaya: Surabaya Statistics Office.

Taussig, M. (1989). 'Terror as usual: Walter Benjamin's theory of history as a state of siege', Social Text 23:3-20.

Verdery, K. (1999). The political lives of dead bodies: Reburial and postsocialist change. New York: Colombia University Press.

Walkin, J. (1969). 'The moslem-communist confrontation in East Java, 1964-1965', Orbis 13-3:822-47.

Woodward, M. (1988). 'The "slametan": Textual knowledge and ritual performance in Central Javanese Islam', History of Religions 28-1:54-89. 